\title{
Genetic divergence and cryptic speciation in two morphs of the common subtidal nudibranch Doto coronata (Opisthobranchia: Dendronotacea: Dotoidae) from the northern Irish Sea
}

\author{
C. C. Morrow ${ }^{1}$, J. P. Thorpe ${ }^{1, *}$, B. E. Picton ${ }^{2}$ \\ ${ }^{1}$ Department of Environmental and Evolutionary Biology, The University of Liverpool, Port Erin Marine Laboratory, \\ Port Erin, Isle of Man, United Kingdom
}

${ }^{2}$ Department of Botany and Zoology, Ulster Museum, Botanic Gardens, Belfast BT9 5AB, Northern Ireland, United Kingdom

\begin{abstract}
The nudibranch genus Doto Oken (Dendronotacea, Dotoidae) contains numerous species which are important specialist predators of subtidal marine hydroids. The widespread species Doto coronata (Gmelin) is of particular taxonomic importance as the type species of the genus. Lemche (1976; J. mar. biol. Ass. U.K. 56: 691-706) identified several cryptic species within D. coronata, but the species is still suspected of being a species complex. Electrophoretic techniques were used to investigate genetic differentiation between 2 morphologically distinct samples of $D$. coronata found feeding on 2 different hydroid species off the south west of the Isle of Man (Irish Sea). The results showed extensive genetic differentiation and indicate that the 2 morphs are separate species. These new species are described and it is suggested that other morphs of $D$. coronata on different hydroid species may represent further new species.
\end{abstract}

\section{INTRODUCTION}

The dotoid nudibranch known as Doto coronata (Gmelin) is common all around the coasts of the British Isles (Thompson \& Brown 1976, 1984) and has a known range in the northeast Atlantic from Iceland and Scandinavia (Lemche 1938, Odhner 1939) to Iberia (Nobre 1905) and the Mediterranean (Odhner 1914. Vincente 1967, Schmekel \& Kress 1977). Records of the species from North America (Loveland et al. 1969) and the Red Sea (O'Donoghue 1929) are regarded as doubtful by Thompson \& Brown (1984). The species apparently occurs intertidally and subtidally down to $180 \mathrm{~m}$. Like most of the several British species of the genus Doto Oken, $D$. coronata, with a maximum length of $12 \mathrm{~mm}$ (Thompson \& Brown 1984), is a fairly small nudibranch. The species is recorded as eating various species of hydroids, with which it is commonly found

\footnotetext{
- Addressee for correspondence
}

associated. Like almost all nudibranchs $D$. coronata is probably semelparous, but it has a short generation time with 2 to 4 generations annually (Miller 1962). $D$. Coronata is the type species of the genus Doto and it is therefore particularly important that this species should be well characterised. Gmelin's (1791) description is based on a specimen collected by Bomme (Bomme 1769) on a hydroid of the genus Eudendrium Ehrenberg from the Dutch coast (see Lemche 1976).

Within the genus Doto there is much confusion concerning the identity and number of species. Thompson \& Brown (1976) considered that there were only 5 British species, but Lemche (1976), in a major revision of the genus in northern Europe, added 6 more. Four of these new species were within what had previously been considered Doto 'coronata', but even so Lemche considered that this species might require further subdivision and consequently did not designate a neotype for $D$. Coronata. Lemche also split $D$. pinnatifida (Montagu) and resurrected an older species, D. maculata (Montagu), previously synonymised with $D$. coro- 
nata. Picton (1978) reviewed the species of Doto then known from the British Isles and suggested that ecological and biochemical genetic techniques could help resolve the taxonomic problems within the genus. Subsequently Picton \& Brown (1981) found D. lemchei Ortea \& Urgorri for the first time in Britain and also described a new species, $D$. hystrix. In a later work Thompson \& Brown (1984) recognised 12 British species within the genus.

The major cause of difficulty in the description and taxonomic separation of Doto species is that many are morphologically very similar. However, Lemche (1976) and Picton (1978) considered that the choice of the hydroid prey was species specific and thus it is possible that within the genus the choice of prey species could be a useful taxonomic character. In nudibranchs generally the importance of highly specific diets in permitting the exploitation of a large number of feeding niches within the group as a whole has long been known (e.g. Thompson 1964). In the present work enzyme electrophoresis was used to examine the extent (if any) of genetic divergence between 2 sympatric morphs of $D$. coronata, one morph occurring on the calyptoblastic hydroid Hydrallmania falcata (L.) and the other on the athecate hydroid Sarsia eximia (Allman). This appears to be the first use of genetic techniques for taxonomic purposes in any dendronotacean nudibranch, although there are earlier studies of other opisthobranchs (e.g. Havenhand et al. 1986).

Enzyme electrophoresis has been used extensively to investigate the genetic structure of natural populations in a wide range of plant and animal species (reviewed by e.g. Nei 1987, Ryman \& Utter 1987). It is a particularly powerful method for solving taxonomic problems and in studies of marine invertebrates it has been useful in distinguishing species in a wide range of phyla (e.g. Grassle \& Grassle 1976. Thorpe et al, 1978a, Solé-Cava et al. 1985) and for quantifying divergence between populations or species (e.g. Macleod et al. 1985, 'Todd et al. 1988). The major advantages of the technique are the objectivity of the analysis, the ease and rapidity with which large amounts of genetic information can be acquired and the relatively unbiased results when compared to those obtained from conventional morphological studies (Avise 1974, Solê-Cava \& Thorpe 1987).

\section{MATERIALS AND METHODS}

Collection of specimens. Samples of Doto coronata (Gmelin) were collected on 25 and 26 June 1991 by Scuba diving close inshore off the southwestern extremity of the Isle of Man (northern Irish Sea). A number of individuals of a particular morph were found on the athecate hydroid Sarsia eximia (Allman) at $15 \mathrm{~m}$ depth off the south of the Calf of Man, a small (ca $2.5 \mathrm{~km}^{2}$ ) island close to the southwestern tip of the Isle of Man. A second group of individuals of a different morph were found feeding on the thecate hydroid Hydallmania falcata (L.) at $20 \mathrm{~m}$ depth off the west of the Calf of Man.

From each of these sites samples of 16 and 14 individuals respectively were taken back to Port Erin Marine Laboratory where they were examined and photographed. Sample sizes were necessarily restricted to prevent elimination or serious depletion of the populations. The specimens collected were maintained alive in an aquarium until required. Four specimens of Doto coronata from each of the 2 sampling localities were preserved for future reference and the remainder were used for the biochemical genetic study. These samples were not subject to prolonged starvation because this is unnecessary; previous work (using other nudibranch species) had already shown that gui conients have nu apparent effects on electrophoretic results. However, since the samples of Doto were kept in the laboratory for some time before running it is unlikely that there was much food in the gut.

Electrophoresis. Elcctrophorcsis was carried out based on standard methods (reviews by Richardson et al. 1986, Murphy et al. 1990) using horizontal $12.5 \%$ starch gels $(180 \times 150 \times 12 \mathrm{~mm})$ on Shandon electrophoresis apparatus. Samples were homogenised in distilled water and run on a continuous Tris-Citrate buffer system, pH 8.0 (Ward \& Beardmore 1977). Gels were cooled by placing the apparatus in a refrigerator (ca $2^{\circ} \mathrm{C}$ ). Running time was $7 \mathrm{~h}$ at $120 \mathrm{~V}$. Power was from Heathkit regulated H.V. power supplies (type IP 1717). The staining of the gels followed standard procedures (Harris \& Hopkinson 1978). To facilitate direct comparison and ensure that all alleles were correctly identified, samples of Doto coronata from each locality were run side by side. Ten enzyme systems were investigated, of which 6 (Isocitrate dehydrogenase, Idh E.C. 1.1.1.42; Malate dehydrogenase, Mdh - E.C. 1.1.1.37; Peptidases, Pep - E.C. 3.4.11.1; Phosphoglucose isomerase, Pgi - E.C. 5.3.1.9; Phosphoglucomutase, Pgm - E.C. 2.7.5.1) could be reliably scored in all samples. Preliminary trial runs could not be used because only a limited number of samples was available. The number of enzymes which could be studied was restricted because of the small sample of tissue which could be extracted from each individual. For the same reason some of the smaller specimens could not be typed for each locus, although for each morphotype the minimum number typed was 8 per locus

Genetic results were analysed using the programme BIOSYS-1 (Swofford \& Selander 1981). To compensate for small sample sizes Fisher's exact probabilities were used to test for fits to Hardy-Weinberg equilibrium (Swofford \& Selander 1981). 


\section{RESULTS}

\section{Electrophoresis}

Sample of each of the 2 morphotypes of Doto coronata were typed successfully for 6 enzymes coding for a total of 9 gene loci. Allle frequency data are summarised in Table 1 Of these 9 loci only 2 (Malate Dehydrogenase-1, Mdh-1; and Phosphoglucomutase2. Pom-2) were monomorphic and identical in all samples, although 3 others (Peptidase, Pep; Phosphoglucose Isomerase-1, Pgi-1; and Mannose Phosphate

Table 1. Doto coronata. Allele frequencies at various enzyme loci in populations collected from the hydroids Hydrallmania falcata and Sarsia eximia. N = number of individuals sampled. Alleles and loci are numbered in order of increasing electrophoretic mobility. Full names of enzymes are given in the text

\begin{tabular}{|c|c|c|c|}
\hline Locus & Allele & On Hydrallmania & On Sarsia \\
\hline \multirow[t]{6}{*}{ Pgi-1 } & 1 & 0.000 & 0.042 \\
\hline & 2 & 0.200 & 0.042 \\
\hline & 3 & 0.500 & 0.792 \\
\hline & 4 & 0.300 & 0.083 \\
\hline & 5 & 0.000 & 0.042 \\
\hline & $N$ & 10 & 12 \\
\hline \multirow[t]{3}{*}{$P g j-2$} & 1 & 1.000 & 0.000 \\
\hline & 2 & 0.000 & 1.000 \\
\hline & $N$ & 10 & 12 \\
\hline \multirow[t]{2}{*}{$M d h-1$} & 1 & 1.000 & 1.000 \\
\hline & $\mathrm{N}$ & 10 & 12 \\
\hline \multirow[t]{3}{*}{$M d h-2$} & 1 & 1.000 & 0.000 \\
\hline & 2 & 0.000 & 1.000 \\
\hline & $N$ & 9 & 12 \\
\hline \multirow[t]{5}{*}{$I d h$} & 1 & 0.050 & 0.000 \\
\hline & 2 & 0.000 & 0.083 \\
\hline & 3 & 0.950 & 0.333 \\
\hline & 4 & 0.000 & 0.583 \\
\hline & $\mathrm{N}$ & 10 & 12 \\
\hline \multirow[t]{5}{*}{ Pep } & 1 & 0.000 & 0.042 \\
\hline & 2 & 0.850 & 0.667 \\
\hline & 3 & 0.150 & 0.250 \\
\hline & 4 & 0.000 & 0.042 \\
\hline & $\mathrm{N}$ & 10 & 12 \\
\hline \multirow[t]{4}{*}{ Mpi } & 1 & 0.000 & 0.045 \\
\hline & 2 & 0.350 & 0.409 \\
\hline & 3 & 0.650 & 0.545 \\
\hline & $\mathrm{N}$ & 10 & 11 \\
\hline \multirow[t]{3}{*}{ Pgm-1 } & 1 & 0.000 & 1.000 \\
\hline & 2 & 1.000 & 0.000 \\
\hline & $N$ & 8 & 10 \\
\hline \multirow[t]{2}{*}{ Pgm-2 } & 1 & 1.000 & 1.000 \\
\hline & $N$ & 10 & 12 \\
\hline
\end{tabular}

Isomerase, Mpi) showed some polymorphism, but no significant differences. A further 3 loci (Malate Dehydrogenase, Mdh-2; Pgi-2; Pgm-1) had no alleles in common between the 2 morphotypes, whilst the remaining locus (Isocitrate dehydrogenase, Idh) was polymorphic, but showed significant $(p<0.05)$ differences between the 2 morphs.

Data summarising levels of genetic variation within each population sampled are given in Table 2. No locus showed significant (Fisher's exact test; $p>0.05$ ) deviations from Hardy-Weinberg expectations for any sample. However, it should be noted that statistical tests of fit to Hardy-Weinberg equilibrium are weak unless sample sizes are large (Lewontin 1958, Fairbairn \& Roff 1980, Valenzuela 1985, Lessios 1992).

Table 2. Doto coronata. Levels of genetic variation in populations collected from the hydroids Hydrallmania falcata and Sarsia eximia. Parameters are mean observed $\left(H_{0 b s}\right)$ and expected $\left(H_{\text {exp }}\right)$ heterozygosity per locus, proportion of loci polymorphic ( $P$, using 0.95 and 0.99 criteria) and mean observed number of alleles per locus

\begin{tabular}{|lccccc|}
\hline Sample & $H_{\text {ohs }}$ & $H_{\text {exp }}$ & $P_{0.95}$ & $P_{0.99}$ & Alleles \\
\hline On Hydrallmania & 0.143 & 0.223 & 0.44 & 0.44 & 2.2 \\
On Sarsia & 0.189 & 0.167 & 0.44 & 0.44 & 1.6 \\
\hline \multicolumn{5}{c}{ Morphology }
\end{tabular}

The specimens studied all had the diagnostic combination of characters (viz. dark red pigmentation, lack of spotting on the cerata other than terminal spots on the tubercles, red pigmentation on the inner faces of the cerata, and ceratal shape) which would identify them as Doto coronata sensu Thompson \& Brown (1976) rather than any of the segregate species described by Lemche (1976). The sample collected from Sarsia eximia appears to be the first record on any Doto species feeding on a Sarsia species. Although the 2 samples of $D$. coronata were similar, careful examination revealed several consistent differences between those found on Hydrallmania falcata and those from S. eximia. These differences are detailed in the descriptions given in the appendix.

\section{DISCUSSION}

The results of the enzyme electrophoresis indicate that there are numerous genetic differences between the sample of the morphotype of Doto coronata found feeding on Hydrallmania falcata and the other sample found on Sarsia eximia. Between sympatric populations of a single species (e.g. conspecific morphs) there should be no significant difference in gene frequency 
at any locus since, by definition, conspecific individuals should be freely interbreeding and thus part of a single population. Therefore among sympatric population any significant variation in gene frequency indicates the probability of the existence of a barrier to gene flow and, consequently, that the 2 populations are likely to be different species. In theory some genetic differentiation between sympatric populations could occur as a result of selection, but in practice the studies of numerous workers over many years indicate that it is unusual for selection to have any substantial or even detectable short-term effect on the frequency of enzyme alleles. In the early days of biochemical population genetics many studies attempted to demonstrate such effects (review by Lewontin 1974), but it is now clear that if selective forces do have any effects on levels of enzyme polymorphism or on allele frequencies such effects are very subtle, and for all practical purposes manifest large selective effects do not occur in natural populations (see e.g. Kimura 1983, Nei 1987 , Hartl \& Clark 1989).

Between the 2 morphotypes of Doto coronata 3 out of the 9 loci andiysed were fixed fur different alleles (diagnostic loci sensu Ayala 1983) and 1 other locus differed significantly. The presence of any locus significantly different between samples provides evidence suggesting a lack of gene flow between populations, thus indicating that the populations are likely to be reproductively isolated. The 2 samples of $D$. coronata were collected from sites less than $2 \mathrm{~km}$ apart in an area of very strong tidal flow (up to about $10 \mathrm{~km} \mathrm{~h}^{-1}$ ). Since all Doto species have a highly mobile feeding planktonic veliger larva it is likely that over such a short distance the 2 populations can safely be regarded as sympatric. Planktotrophic veligers are considered to swim in the plankton for a minimum of $3 \mathrm{~d}$ and often for several weeks (Thompson 1976) and thus will be widely dispersed, although a few nudibranchs with lecithotrophic veligers may have only limited dispersal capabilities (see for example Todd et al. 1988). If the populations we have studied are considered to be sympatric it follows that the 2 reproductively isolated morphotypes are unlikely to be conspecific.

However, independently of whether they are sympatric, even stronger evidence that the 2 morphotypes are not the same species is provided by the level of genetic differentiation between them. Overall levels of genetic divergence between population or species can be reduced to a single value using any of various published statistical indices of genetic similarity, identity or distance (see e.g. Thorpe 1979, 1982, Nei 1987). The most commonly used measure is the genetic identity measure, I, of $\mathrm{Nei}$ (1972). This statistic ranges from 1 (if populations are genetically identical) to 0 (total dissimilarity with no genes in common). There are many studies available giving levels of genetic divergence observed between various populations and species in a very wide and diverse range of animals and plants (reviews by Thorpe 1982, 1983, Nei 1987). Generally conspecific populations have $I$ values above about 0.9 and rarely as low as 0.8 , whilst identity levels between congeneric species can be expected to range from about 0.3 to 0.8 , and species from different, but confamilial, genera usually show I values below about 0.4 .

Nei's (1972) genetic distance, $D$, which is the converse of his genetic identity and ranges from 0 (no differences) to infinity (no genes in common) can be calculated from $I$ using $D=-\log _{\mathrm{e}} I$. Given the assumptions of the 'molecular clock' hypothesis (reviews by e.g. Wilson et al. 1977, Thorpe 1982, see also Nei 1987 , Thorpe 1989) genetic distance values may be stochastically related to evolutionary time.

A feature of Nei's $I$ and $D$ is that sampling errors for estimates of genetic divergence between species are little affected by numbers of individuals used and depend almost entirely on the number of genetic (in this case enzyme coding) loci analysed (Nei \& RoyChoudhury 1974, Thorpe 1979). For the estimation of divergence between species even samples sizes as small as 1 individual will give fairly robust estimates of I or D (Nei 1978, Gorman \& Renzi 1979, Thorpe 1982).

Between the 2 morphotypes of Doto coronata Nei's (1972) genetic identity, $I$, is 0.526 and genetic distance, $D$, is 0.632 . The I value falls within the lower half of the range expected for congeneric species (Thorpe 1982) and is well outside that expected between conspecific populations. Indeed an $I$ value of 0.526 is very close to that of 0.432 reported by Havenhand et al. (1986) for a genetic comparison between the dorid nudibranchs Adalaria proxima (Alder \& Hancock) and Onchidoris muricata (Müller), which are conventionally placed in different genera. The $D$ value observed between the 2 morphotypes of $D$. coronata indicates a long period of evolutionary divergence (at least a few million years) although no specific calibration of the genetic distance molecular clock is available for opisthobranchs. The sample sizes (numbers of individuals) used here (12 and 10) were necessarily restricted in order not to seriously deplete the only known populations. Although small by the standards of conventional systematic research these samples are, as discussed above, more than adequate for the estimation of $I$ and $D$. Overall, therefore, the levels of genetic differentiation between the 2 samples provide strong evidence that they are from 2 different species.

Our results indicating cryptic speciation demonstrated by fixed allelic difference are very similar to those described in a wide range of organisms in which cryptic speciation has been detected by biochemical genetics. There are many such studies on marine 
animals including for example fish (e.g. Smith \& Robertson 1981, Sole-Cava et al. 1983), sea anemones (e.g. Carter \& Thorpe 1981, Haylor et al. 1984, Shaw et al. 1988), hydroids (e.g. Thorpe et al. 1992), polychaetes (e.g. Grassle \& Grassle 1976), sponges (e.g. Sole-Cava et al. 1991, Boury-Esnault et al. 1992), bryozoans (e.g Thorpe et al. 1978a, b, Thorpe \& Ryland 1979), echinoderms (e.g. Mladenov \& Emson 1990), cephalopods (e.g. Smith et al. 1981, Thorpe et al. 1986) and pycnogonids (King et al. 1986). These and many other studies show that occasionally marine species can acquire comparatively high levels of genetic differentiation without showing morphological differences which taxonomists would regard as adequate to indicate speciation. Conversely there are also some cases where morphological differences have caused taxonomists to describe as species morphs which subsequent genetic studies suggest are conspecific (e.g. Maturo \& Thorpe 1979, Moyse et al. 1982). Thus levels of genetic differentiation between morphs or species may not, in some cases, be reflected in morphological variation, or at least not in that which is apparent to us. However in many studies where allegedly conspecific morphs have proved to be quite distinct genetic species the problem may lie more in the choice of taxonomic characters on which the species are defined (for example, various genetically very distinct sponge species have been regarded previously as conspecific merely because the spicules did not differ, although there were clear differences of colour, form or choice of substratum, e.g. Sole-Cava \& Thorpe 1986, Sole-Cava et al. 1991, Boury-Esnault et al. 1992). In the present work the 2 Doto species would not have been considered different species on the basis of conventional characters used to distinguish species within the genus. Between the two there are however fairly clear differences in coloration and patterning, obvious differences in choice of prey species and more minor but consistent differences in external morphology. Hence the species differences were cryptic not because the species were indistinguishable but because the conventional taxonomic criteria would appear to be either wrong or inadequate to distinguish all species within the genus.

Values for various parameters used to estimate levels of intraspecific genetic variation are given in Table 2. These are included because, in contrast to most other molluscan groups, very few data of this kind have been published for nudibranchs. Values for mean heterozygosity per locus (range 0.14 to 0.22 ) are unusually high when compared to most other animal species, but not exceptionally so (see reviews by Nevo 1978, Nevo et al. 1984). Havenhand et al. (1986) gave a much lower range of 0.05 to 0.08 for 2 dorid species.

It is clear from the genetic evidence discussed above that the 2 samples of Doto studied are from 2 distinct species. As mentioned above and discussed by Lemche (1976) the original description of $D$. coronata is of an individual collected from the eastern coast of the North Sea feeding on a species of Eudendrium. There must, therefore, be doubt as to whether either of our 2 species is $D$. coronata and yet it is important that both should have names. For subsequent workers it will be easier to possibly synonymise new names than to separate different biological species incorrectly synonymised. Hence for both of the species discussed here it is considered desirable to create new names until specimens on Eudendrium from the North Sea can be investigateed and compared with the present species. Thus it is proposed that the specimens on Sarsia eximia (Allman) should be known as Doto sarsiae sp. nov. and those found on Hydrallmania falcata (L.) should be known as Doto hydrallmaniae sp. nov. Detailed descriptions are given in the appendix. For each of our 2 new species a type specimen and 3 paratypes together with 2 colour (photographic) slides have been deposited at the British Museum (Natural History) in London.

The classification of nudibranchs is traditionally based on such characters as the structure of the radula, reproductive organs and digestive system and to a lesser extent body shape, colour and patterning. However in the genus Doto species level taxonomy is becoming increasingly difficult because interspecific morphological variation is often slight. The main differences between $D$. sarsiae and $D$. hydrallmaniae were observed in the morphology of the cerata and oral veil, the distribution of the subcutaneous white glands, the presence of pigment spots on the rim of the rhinophore sheath, the body colour and the size of pigment spots on the tubercles on the cerata. However is should be remembered that both species fall within the range of morphological variation previously considered to be encompassed by $D$. coronata.

Ideally it would be desirable to examine further specimens of the 2 species from other localities. However at the time of collection no other sampling areas were found where either of the 2 species occurred, although presumably in the future other populations will be discovered. Without examination of further samples at, for example, various ages, times of the year, sampling localities or depths it is difficult to be clear which characters are likely to be of systematic value. For example, in some nudibranch species the colour of the digestive gland is influenced by the diet. This can be misleading, as in the aeolid nudibranch Coryphella gracilis (Alder $\&$ Hancock), which can have bright red or green ceratal contents depending on the species of Eudendrium eaten. The green form was originally described as $C$. smaragdina (Alder \& Hancock). Because of such problems there is an increasing need for new diagnostic features. Lemche (1976), as well as studying the morphol- 
ogy, colour patterns and other conventional features in Doto species, also noted the shape of the spawn coils. In some Doto species the shape of the spawn coil is distinctive, indeed in D. tuberculata Lemche, 1976 it is diagnostic. For the species described here the shapes of the spawn coils are not taxonomically useful because they do not differ between the 2 species and are similar to those described for $D$. coronata by Lemche (1976).

Lemche's detailed study also suggested that for Doto species the species of hydroid chosen as food may prove to be a useful taxonomic character, an idea supported by Picton (1978). Our results provide further evidence in favour of this suggestion, which is why the specific names sarsiae (of Sarsia) and hydrallmaniae (of Hydrallmania) have been chosen for the species we have studied.

However, from field observations by one of us (B.E.P.) it appears likely that food differences may be even more clearcut than Lemche's data indicate, although there may still be overlap between species. These studies do not always confirm some of the food species identified by Lemche. For example Doto tuberculata is a distinctive species and is not uncommon; in Britain it appears to feed only on Sertularella gayi (Lamouroux), but Lemche described it also from Abietinaria abietina (L.). Doto koenneckeri Lemche, 1976 is also distinctive, and in Britain is always found on the thecate hydroid Aglaophenia pluma (L.), but according to Lemche (1976) occurs only on Thecocarpus myriophyllum (L.). Collection of material (by B.E.P.) from the type locality (described in detail in a letter from Lemche) indicates that this apparent discrepancy is a result of Lemche's misidentification of the hydroid species. The type locality is a tidal rapid where $D$. koenneckeri is found on abundant A. pluma. T. myriophyllum does not occur there and indeed would not be expected to do so since it is only found in deep water.

The very different species Doto lemchei has been found by one of us (B.E.P.) at several localities, but always on Aglaophenia tubulifera Lamouroux. In the laboratory $D$. lemchei has been observed to feed on the more common A. pluma, yet in the field it has never been found with this hydroid. A possible explanation is that the mechanism for prey-specificity in Doto is likely to be determined at settlement of the larvae, as has been shown for many nudibranchs (see recent review by Havenhand 1991). Thus many species may be able to eat hydroids on which they do not occur naturally. At present data on the distribution of Doto species and their choice of hydroid prey are at best patchy. It may be that prey species vary between areas or that some Doto species do show overlap in prey. It may also be that many Doto species have highly restricted dietary

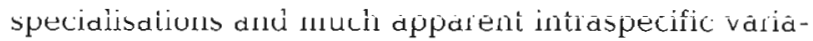
tion in diet could result from failure to distinguish, as yet undescribed, cryptic or sibling species. The electrophoretic results presented here show unequivocally that 2 groups of nudibranchs appearing very similar, but occurring on different hydroids, are distinct species; it is likely that other similar but distinct morphotypes of $D$. coronata from other hydroids may also prove to be new species.

Appendix. Detailed descriptions of the 2 species of dotoid nudibranch discussed in this paper

\section{(a) Specimens on Sarsia eximia (Allman)}

Doto sarsiae sp. nov. The body length is normally up to $10 \mathrm{~mm}$ but some individuals may reach $12 \mathrm{~mm}$. The oral veil is semicircular, with a broad, rounded, frontal margin and a straight rear margin to the lateral flaps. The longitudinal, dorso-lateral, head crests are prominent, running from the bases of the rhinophore sheaths to the base of the oral veil. The rhinophores are cylindrical, tapering to a blunt, rounded, tip. The rhinophore sheaths are cylindrical in the basal two thirds, flaring abruptly in the distal third. The distal margin is longer at the front, sloping at about $45^{\circ}$ to the axis of the rhinophore, and smoothly rounded. Well-grown specimens have 7 pairs of cerata. The genital opening is placed below and slightly in tront of the first ceras on the right-hand side of the body, while the anal papilla is placed midway between the first and second cerata on the right side. The cerata are club-shaped, thinner in the proximal portion, reaching maximum diameter at three quarters of their length, then tapering quickly to a blunt terminal tubercle. On the outer face of the cerata there are typically 5 rows of tubercles in the larger cerata. The pseudobranch is usually well-developed on the inner face of the larger cerata, consisting of 3 trans- parent ridges in rounded tubercles distally; in the largest cerata 2 extra, smaller ridges may be present, outside and below the primary 3 . The tubercles may bear pigment spots. The foot does not extend far beyond the last pair of cerata, and ends abruptly in a semicircle, without narrowing appreciably.

The body colour is a hyaline white, with the ovotestis showing through as a creamy-white lobular mass. Dark red pigment spots cover the dorsum and the sides of the body, extending up to the bases of the cerata, over the dorsal surface of the head, onto the basal inner surfaces of the rhinophore sheaths and down the front of the head between the dorso-lateral crests and onto the oral veil. where they extend laterally just beyond the intersections with the head crests. The ceratal tubercles all bear round dark red terminal spots. The digestive gland is bright pink and shows clearly through the transparent cerata walls. Each ceratal tubercle has a few (normally between 2 and 8) subcutaneous white glands embedded in its tip. Similar white glands are present in the distal half of the rhinophores, becoming more concentrated towards the tips. There are no such glands in the rim of the rhinophore sheaths. A small area of red pigment is normally present on the inner faces of the cerata. 


\section{(b) Specimens on Hydrallmania falcata (L.)}

Doto hydrallmaniae sp. nov. The body length is up to $12 \mathrm{~mm}$ but individuals may mature at smaller size. The oral veil is short at the front but extends laterally into 2 broad flaps, being rectangular in overall outline. Lontitudinal, dorso-lateral, head crests are present, but not prominent, running from the bases of the rhinophore sheaths to the base of the oral veil. The rhinophores are cylindrical, tapering to a blunt, rounded, tip. The rhinophore sheaths are cylindrical in the basal half, and bell-shaped in the distal half. The distal margin in slightly longer at the front, sloping at about $20^{\circ}$ to the axis of the rhinophore. The margin is usually slightly scalloped. Well-grown specimens have 9 or 10 pairs of cerata. The genital opening is placed below, but not in front of, the first ceras on the right-hand side of the body, while the anal papilla is placed midway between the first and second cerata on the right side, and median to a line joining their bases. The cerata are long and club-shaped, with a narrow base, reaching maximum diameter at just over half of their length, then tapering to a blunt terminal tubercle. On the outer face of the cerata there are typically 5 or 6 rows of tubercles in the larger cerata, with as many as 9 tubercles in the third row from the top. The 3 inner tubercles in this row represent the tips of the pseudobranch, and are enlarged and bear pigment spots. The wing-like ridges of typical pseudobranch structure are aimost entirely absent in this species. The foot extends beyond the last pair of cerata, tapering to a blunt, rounded point.

The body colour is a hyaline white, with the ovotestis showing through as a creamy-white lobular mass. Dark red pigment spots cover the dorsum and the sides of the body; these are mostly elongate with ill-defined margins, especially on the dorsum. As in several other species of this complex (e.g. Doto dunnei Lemche, 1976) the spots leave a well-defined, clear circle around the bases of the cerata. More well-defined spots cover the dorsal surface of the head and extend onto the basal inner surfaces of the rhinophore sheaths and down the front of the head between the dorso-lateral crests but not onto the oral veil. The ceratal tubercles all bear round dark red terminal spots. The digestive gland is grey-brown and shows clearly through the transparent ceratal walls. Each ceratal tubercle has many (typically 12 to 15 ) subcutaneous white glands embedded in its tip. Similar white glands are present in the distal half of the rhinophores, becoming more concentrated towards the tips, and in the rim of the rhinophores sheaths. In the region of the pseudobranch an area of dark brown-red pigment marks the inner face of each ceras.

As mentioned in the text, for each of these 2 new species a type specimen, 3 paratypes and 2 colour slides of the living animals have been deposited at the British Museum (Natural History), Cromwell Road, London SW7.
Acknowledgements. The authors thank John Bishop for help with the electrophoresis and discussion of the results. The fieldwork was carried out during a survey of the Calf of Man funded by the Isle of Man Government and the Worldwide Fund for Nature. Thanks are due to the divers from the Port Erin Marine Laboratory for logistical support and to Prof. T A. Norton for the provision of facilities.

\section{LITERATURE CITED}

Avise, J. C. (1974). The systematic value of electrophoretic data. Syst. Zool. 23: 465-481

Ayala, F. J (1983). Enzymes as taxonomic characters. In: Oxford, G. S., Rollinson, D. (eds.) Protein polymorphism: adaptive and taxonomic significance. Academic Press, London, p. 3-26

Bomme, L. (1769). Bericht wegens een zonderling Zee-insect, gefonden aan eenige zeewieren gewischt op het strand van het eiland Walcheren. Verhandelingen der Zeeuwsche Genootschaft Vlissingen 1: 394-409

Boury-Esnault, N., Sole-Cava, A. M., Thorpe, J. P. (1992). Genetic and cytological divergence between colour morphs of the Mediterranean sponge Oscarella lobularis Schmidt (Porifera, Demospongiae, Oscarellidae). J. nat. Hist. (in press)

Carter, M. A, Thorpe, J. P. (1981). Reproductive, genetic and ecological evidence that Actinia equina var. mesembryanthemum and var. fragacea are not conspecific. J. mar. biol. Ass. U.K. 61: 79-83

Fairbairn, D. J., Roff, D. A. (1980). Testing genetic models of isozyme variability without breeding data: can we depend on the $x^{2}$ ? Can. J. Fish. Aquat. Sci. 37: 1149-1159

Gorman, G. C., Renzi, J. (1979). Genetic distance and heterozygosity estimates in electrophoretic studies: effects of sample size. Copeia 1979: 242-249

Grassle, J. P., Grassle, J. F. (1976). Sibling species in the marine pollution indicator, Capitella capitata (Polychaeta). Science 192: $567-569$

Harris, H., Hopkinson, D. A. (1978). Handbook of enzyme electrophoresis in human genetics. North Holland, Amsterdam

Hartl, D. L., Clark, A. G. (1989). Principles of population genetics. Sinauer Associates, Sunderland, Massachusetts

Havenhand, J. N. (1991). On the behaviour of opisthobranch larvae. J. mollusc Stud. 57: 119-131

Havenhand, J. N., Thorpe, J. P., Todd, C. D. (1986). Estimates of biochemical genetic diversity within and between the nudibranch molluscs Adalaria proxima (Alder \& Hancock) and Onchidoris muricata (Müller) (Doridacea: Onchidorididae). J exp. mar. Biol. Ecol. 95: $105-112$

Haylor, G. S., Thorpe, J. P., Carter, M. A. (1984). Genetical and ecological differentiation between sympatric colour morphs of the common intertidal sea anemone Actinia equina. Mar. Ecol. Prog. Ser. 16: 281-290

Kimura, M. (1983). The neutral theory of molecular evolution. Cambridge University Press, Cambridge

King, P. E., Thorpe, J. P., Wallis, G. P. (1986). A biochemical genetic and morphological investigation of the species within the genus Endeis Philippe (Pycnogonida; Endeidae) in Britain. J. exp. mar. Biol. Ecol. 98: 115-128

Lemche, H. (1938). Gastropoda Opisthobranchiata. Zoology Iceland 4: 1-54

Lemche, H. (1976). New British species of Doto Oken, 1815 (Mollusca: Opisthobranchia). J. mar. biol. Ass. U.K. 56: 691-706

Lessios, H. A. (1992). Testing electrophoretic data for agreement with Hardy-Weinberg expectations. Mar Biol. 112: $517-523$ 
Lewontin, R. C. (1958). A general method for investigating the equilibrium of gene frequencies in a population. Genetics 43: $419-434$

Lewontin, R. C. (1974). The genetic basis of evolutionary change. Columbia University Press, New York

Loveland, R. E., Hendler, G., Newkirk, G. (1969). New records of nudibranchs from New Jersey. Veliger 11:418-420

Macleod, J A. A., Thorpe, J. P., Duggan, N. A. (1985). A biochemical genetic study of queen scallop (Chlamys opercularis) stocks in the northern Irish Sea. Mar. Biol. 87: $77-82$

Maturo, F. J. S. Jr, Thorpe, J. P. (1979). The relationship of Schizomavella linearis (Hassall) and $S$. hastata (Hincks). In: Larwood, G. P., Abbott, M. B. (eds.) Advances in bryozoology. Academic Press, London, p. 431-442

Miller, M. C. (1962). Annual cycles of some Manx nudibranchs, with a discussion of the problem of migration. J. Anim. Ecol. 31. 545-569

Mladenov, P. V., Emson, R. H. (1990). Genetic structure of populations of two closely related brittle stars with contrasting sexual and asexual life histories with observations on the genetic structure of a second asexual species. Mar. Biol. 104: 265-274

Moyse, J., Thorpe, J. P., Al-Hamadani, E. (1982). The status of Littorina aestuariae Jeffreys, an approach using morphology and biochemical genetics. J. Conchol. 31: 7-15

Murphy, R. W., Sites, J. W. Buth, D. G., Haufler, C. H. (1990). Proteins I. Isozyme electrophoresis. In: Hillis, D. M., Moritz, C. (eds.) Molecular systematics. Sinauer Associates, Sunderland, Massachusetts, p. 45-126

Nei, M. (1972). Genetic distance between populations. Am. Nat. 106: 283-292

Nei, M. (1978). Estimation of average heterozygosity and genetic distance from a small number of individuals. Genetics 89: 583-590

Nei, M. (1987). Molecular evolutionary genetics. Columbia University Press, New York

Nei, M., Roychoudhury, A. K. (1974). Sampling variances of heterozygosity and genetic distance. Genetics 76: 379-390

Nevo, E. (1978). Genetic variation in natural populations: patterns and theory. Theor. Populat. Biol. 13:121-177

Nevo, E., Beiles, A., Ben-Schlomo, R. (1984). The evolutionary significance of genetic diversity: ecological, demographic and life history correlates. In: Mani, G. S. (ed.) Evolutionary dynamics of genetic diversity. Springer-Verlag, Heidelberg, p. 13-212

Nobre, A. (1905). Mollusques et brachiopodes du Portugal Annls Sci. nat zool. Biol. anim. 8: 1-147

Odhner, N. H. (1914). Beiträge zur Kenntnis der marinen Molluskenfauna von Rovigno in Istrien. Zool. Anz. 44: $156-170$

Odhner, N. H. (1939). Opisthobranchiate Mollusca from the western and northern coasts of Norway. K. norske Vidensk. Selsk Skr. 1: 1-92

O'Donoghue, C. H. (1929). Report on the Opisthobranchiata with a comparison of the nudibranch fauna of the Red Sea and of the Mediterranean. Trans. Zool. Soc. Lond. 22 $713-841$

Picton, B. E. (1978). A review of the Genus Doto (Mollusca Opisthobranchia) in the N.E. Atlantic and Mediterranean. Porcupine Newsletter 1: 64-77

Picton, B. E., Brown, G. H. (1981). Four nudibranch gastropods new to the fauna of Great Britain and Ireland including a description of a new species of Doto Oken Ir. Nat. J. 20: 261-268

Richardson, B. J., Baverslock, P. R., Adams, M. (1986) Allozyme electrophoresis. Academic Press, Sydney
Ryman, N. Utter, F. (1987). Population genetics and fishery management. University of Washington Press, Seattle

Schmekel, L., Kress, A. (1977). Die Gattung Doto (Gastro. poda: Nudibranchial im Mittelmeer und Ärmelkanal mit Beschreibung von Doto acuta n. sp. Malacologia 16 $4647-499$

Shaw, P. W. Beardmore, J. A., Ryland, J. S. (1988). Sagartia troglodytes (Anthozoa: Actiniaria) consists of two species Mar. Ecol. Prog. Ser. 41:21-28

Smith, P. J., Roberts, P. E., Hurst, R. J. (1981). Evidence for two species of arrow squid in the New Zealand fishery. N.Z. J. mar. Freshwat. Res. 15: 247-253

Smith, P. J., Robertson, D. A. (1981). Genetic evidence for two species of sprat (Sprattus) in New Zealand waters. Mar Biol. 62: 227-233

Solé-Cava, A. M., Klautau, M., Boury-Esnault, N., Borojevic, R., Thorpe, J. P. (1991). Genetic evidence for cryptic speciation in allopatric populations of two cosmopolitan species of the calcareous sponge genus Clathrina. Mar. Biol. 111 $381-386$

Solé-Cava, A. M., Thorpe, J. P. (1986). Genetic differentiation between morphotypes of the marine sponge Suberites ficus (Demospongiae: Hadromerida). Mar. Biol. 93: 247-253

Solé-Cava, A. M., Thorpe, J. P. (1987). The uses of electrophoresis in sponge taxonomy. In: Vacelet, J., BouryEsnault, N. (eds.) Taxonomy of Porifera. Springer Verlag. Berlin, p. 243-258

Solé-Cava, A. M., Thorpe, J. P., Kaye, J. G. (1985) Reproductive isolation with little genetic divergence between Urticina ( $=$ Tealia) felina and $U$. eques (Anthozoa: Actiniaria) Mar. Biol. 85: 279-284

Solé-Cava, A. M., Vooren, C. M., Levy, J. A. (1983). Isozymic differentiation of two sibling species of Squattina (Chondrichthyes\} in South Brazil. Comp. Biochem. Physiol. 75B $355-358$

Swofford, D. L., Selander, R. K. (1981). BIOSYS-1: a FORTRAN program for the comprehensive analysis of electrophoretic data in population genetics and systematics. J. Hered. 72: 281-283

Thompson, T. E. (1964). Grazing and the life cycles of British nudibranchs. Brit. ecol. Soc. Symp. 4: 275-297

Thompson, T E. (1976). Biology of opisthobranch molluscs Vol. 1. Ray Society, London

Thompson, T E., Brown, G. H. (1976). British opisthobranch molluscs. Linnean Society, London

Thompson, T E., Brown, G. H. (1984). Biology of opisthobranch molluscs, Vol. 2. Ray Society, London

Thorpe, J. P. (1979). Enzyme variation and taxonomy: the estimation of sampling errors in measurements of interspecific genetic similarity. Biol. J. Linn. Soc. 11: 369-386

Thorpe, J. P. (1982). The molecular clock hypothesis: biochemical evolution, genetic differentiation and systematics. Ann. Rev. Ecol. Syst. 13: 139-168

Thorpe, J. P. (1983). Enzyme variation, genetic distance and evolutionary divergence in relation to levels of taxonomic separation. In: Oxford, G. S., Rollinson, D. (eds.j Protein polymorphism: adaptive and taxonomic significance. Academic Press, London, p. 131-152

Thorpe, J. P. (1989). Possible effects of interprotein variation in mean rate of amino acid substitution on the relationship of genetic distance with time since evolutionary divergence. J. Linn Soc. (Biol) 37: 335-344

Thorpe, J. P., Beardmore, J. A., Ryland, J. S. (1978a). Genetic evidence for cryptic speciation in the marine bryozoan Alcyonidium gelatinosum. Mar. Biol. 49: 27-32

Thorpe, J. P., Havenhand, J. N., Patterson, K. (1986). Report of the University of Liverpool (Department of Marine 
Biology) to the Falkland Islands Development Corporation. Stock and species identities of Patagonian Shelf Illex. Falkland Islands Development Corporation, Port Stanley, Falkland Islands, $23 \mathrm{pp}$.

Thorpe, J. P., Ryland, J. S. (1979). Cryptic speciation detected by biochemical genetics in three ecologically important species of intertidal bryozoans. Estuar. coast. mar. Sci. 8: $395-398$

Thorpe, J. P., Ryland, J. S., Beardmore, J. A. (1978b). Genetic variation and biochemical systematics in the marine bryozoan Alcyonidium mytili. Mar. Biol. 49: 343-350

Thorpe, J. P., Ryland, J. S., Cornelius, P. F. S., Beardmore, J. A. (1992). Evidence for extensive genetic divergence between branched and unbranched forms of the marine thecate hydroid Aglaophenia pluma. J. mar. biol. Ass. U.K. (in press)

This article was submitted to the editor
Todd, C. D., Havenhand, J N., Thorpe, J P. (1988). Genetic differentiation, pelagic larval transport and gene flow between local populations of the intertidal marine mollusc Adalaria proxima (Alder and Hancock). Funct. Ecol. 2: $441-451$

Valenzuela, C. Y (1985). Algebraic and epistemological restrictions in studies on Hardy-Weinberg equilibrium. Am. Nat. 125: 744-746

Vincente, N. (1967). Contribution à l'étude des gastéropodes opisthobranches du golfe de Marseille. Recl. Trav. Stn mar. Endoume 42: 133-179

Ward, R. D., Beardmore, J. A. (1977). Protein variation in the plaice (Pleuronectes platessa). Genet. Res. 30: 45-62

Wilson, A. C., Carlson, S. S., White, T. J. (1977). Biochemical evolution. Ann. Rev. Biochem. 46: 573-639

Manuscript first received: January 2, 1992

Revised version accepted: May 19, 1992 